\title{
OECD Ülkelerinde İşsizlik Histerisinin Ampirik Bir Analizi: Fourier Panel Durağanlık Testi
}

\section{An Empirical Analysis of the Unemployment Hysteresis in OECD Countries: Fourier Panel Stationary Tests}

\author{
Ŭ̆ur Korkut PATA* \\ (iD) 0000-0002-2853-4106
}

Sosyal Güvenlik Dergisi / Journal of Social Security Cilt: 10 Say1: 1 Y11: 2020 /Volume: 10 Issue: 1 Year: 2020 Sayfa Aralığı: 125-144 Pages: 125-144

DOI: 10.32331/ sgd.753027

\section{ÖZ}

İşsizlik toplumun her kesimini ilgilendiren büyük bir konudur. Yüksek işsizlik oranı hem arz hem de talep kanalıyla çeşitli problemlere sebebiyet verebilmektedir. $\mathrm{Bu}$ nedenle işsizlik oranının karakteristik özelliklerini analiz etmek oldukça önemlidir. İktisat teorisinde, işsizlik histerisi ve doğal oran hipotezleri yüksek işsizlik oranının geçici mi yoksa kalıcı mı olduğuna karar vermek için test edilmektedir. Bu çalışma 1991q12019q2 dönemi için 15 OECD ülkesinde ișsizlik histerisinin geçerliliğini Bahmani-Oskooee, Chang ve $\mathrm{Wu}$ (2014) tarafindan geliştirilen Fourier panel durağanlık testini kullanarak incelemektedir. Durağanlık testinin sonuçları panelin tamamı için işsizlik histerisi hipotezinin geçerliliğini desteklememektedir. Ancak, ülke özelindeki sonuçlar açısından, Almanya, Türkiye ve İspanya'da işsizlik histerisi geçerlidir. Bu bulgulara göre, hükümetler işsizlikle mücadele için makroekonomik politikaları etkin bir şekilde kullanabilirler. Aksine, geride kalan 12 OECD ülkesinde ise doğal oran hipotezi geçerlidir. Bu ülkeler için kısa süreli şokların işsizlik oranı üzerindeki etkileri geçicidir. Dolayısıyla, çalışmanın temel bulgusu 15 OECD üyesi ülkenin 12'si için fiili işsizlik oranlarının uzun dönemde doğal işsizlik oranı değerine geri döneceği göstermektedir.

Anahtar Sözcükler: İşsizlik histerisi, fourier pane durağanlık testi, OECD ülkeleri

\section{ABSTRACT}

Unemployment is a major issue that concerns all segments of society. High unemployment rate can cause various problems through both supply and demand channels. It is therefore important to analyze the characteristics properties of the unemployment rate. In economic theory, the unemployment hysteresis and natural rate hypotheses are tested to decide whether high unemployment rate is temporary or permanent. This study examines the validity of the unemployment hysteresis in 15 OECD countries for the period 1991q12019q2 using the Fourier panel stationary test developed by Bahmani-Oskooee Chang and Wu (2014). The results of the stationary test do not support the unemployment hysteresis for the panel as a whole. However, in terms of country specific results, the unemployment hysteresis is valid in Germany, Turkey and Spain. According to these results, governments can effectively use macroeconomic policies to fight against unemployment. In contrast, the natural unemployment rate hypothesis is valid in the remaining 12 OECD countries. The effects of short-run shocks on unemployment rate are temporary for these countries. Thus, the main finding of the study shows that actual unemployment rates will return to the natural unemployment rate for 12 out of 15 OECD countries in the long-run.

Keywords: Unemployment hysteresis, fourier panel stationary test, OECD countries

Önerilen atıf şekli: Pata, U. K. (2020). OECD Ülkelerinde İşsizlik Histerisinin Ampirik Bir Analizi: Fourier Panel Durağanlık Testi. Sosyal Güvenlik Dergisi (Journal of Social Security). 10(1). 125-144.

\footnotetext{
* Dr., Osmaniye Korkut Ata Üniversitesi, İktisadi ve İdari Bilimler Fakültesi, İktisat Bölümü, korkutpata@osmaniye.edu.tr
} 


\section{GİRIŞ}

Geçmişten günümüze ülkeler çeşitli makroekonomik hedefleri gerçekleştirmeyi amaçlayarak toplumsal refah düzeyini arttırmaya çalışmaktadırlar. Bu amaçlardan en önemlileri; düşük bir enflasyon oranı, düşük bir işsizlik oranı, düşük bir faiz oranı ve yüksek bir ekonomik büyüme oranına erişebilmektedir. Dört temel hedeften işsizlik toplumun tüm kesimi için oldukça önemlidir. İşsizlik, enflasyon gibi önemli makroekonomik değişkenleri, aynı zamanda insanların mutluluğunu ve ruhsal sağlı̆̆ını etkilemektedir (Fosten ve Ghoshray, 2011: 948).

İşsizlik, çalışmak isteyen işgücünün ne kadarının istihdam edilemediğinin bir göstergesidir. Ekonomideki en önemli üretim faktörlerinden biri olan emeğin atıl kullanılması hükümetlerin arzu etmediği bir durumdur. Çünkü işsizlik ekonominin hem talep hem de arz kanalını etkilemektedir. Çalışacak durumda olup istihdam edilemeyen bireyler üretime katkı sağlayamamaktadır. Bu nedenle potansiyelden daha az toplam arz ve katma değer gerçekleştirilmektedir. Ayrıca istihdam edilemeyen bu bireyler gelir elde edemediklerinden ötürü harcama kanalında tüketim mallarına yeteri kadar talepte bulunamamaktadırlar. Dolayısıyla işsizlik hem üretim hem de tüketim kanalıyla ülke ekonomilerini olumsuz yönde etkilemektedir.

1973 arz kaynaklı petrol krizi ile birlikte yüksek işsizlik oranları yaşanmış ve bazı ülkelerde bu oranlar uzun süre azaltılamamıştır. Özellikle bu tarihten itibaren işsizlik oranlarındaki artışın geçici mi yoksa kalıcı bir olgu mu olduğu çeşitli ampirik çalışmalarda incelenmeye ve tartışılmaya başlanmıştır.

İşsizlikteki artışın kalıcı mı yoksa geçici mi olduğu üç temel hipotez ile test edilmektedir. Bunlardan ilki Friedman (1968) ve Phelps $(1967,1968)$ tarafindan savunulan doğal işsizlik hipotezidir. Her iki çalışmada işgücü piyasasında arz ve talep tam olarak sağlanamadığından ötürü iş arayan bir kesimin işsiz kalabildiği ve bu nedenle doğal işsizlik oranı olarak nitelendirilen bir miktar işsizliğin olduğu tespit edilmiştir. Asgari ücret gibi yasal düzenlemelerden ötürü daha düşük ücretle çalışmaya razı olan kişiler iş aradıkları halde işsiz kalabilmektedir. Makroekonominin temel fikirlerinden biri olan doğal işsizlik oranı işgücü piyasasındaki denge tarafından belirlenmektedir. Arz ve talepteki oynaklıklar nedeniyle fiili işsizlik oranı doğal işsizlik oranını aşsa da bu durum enflasyonda bir değişmeye sebebiyet vererek nihai olarak fiili işsizlik oranının doğal işsizlik oranına dönmesini sağlayacaktır (Song ve Wu, 1998: 181). Doğal işsizlik oranı hipotezi, doğal işsizlik oranı gerçekleşen işsizlik oranına eşit olduğunda enflasyonun sabit kalabileceğini belirtmektedir. İşsizlik oranındaki kısa süreli sapmalar nedeniyle oluşan artışa müdahale, enflasyonun gereksiz bir şekilde artışına sebebiyet verecek ve işsizlik doğal orana geri döndüğünde de yüksek enflasyon devam edecektir (Canarella, Gupta, Miller ve Pollard, 2019: 62). Bu sebeple doğal işsizlik oranı geçerli olduğunda işsizliğe müdahale edilmemesi gerekmektedir. İşsizlik oranı kısa süreli artış veya azalış gösterse de uzun dönemde bu doğal oran etrafinda dalgalanacaktır. Tam rekabet piyasalarında gerçekleşen doğal işsizlik oranı ekonomik koşullara göre ülkeden ülkeye değişiklik gösterebilmektedir. Friedman ve Phelps'e göre savaş, kriz, enflasyon ve çeşitli yapısal değişimler nedeni ile işsizlik kısa dönem Phillips eğrisinde olduğu gibi geçici bir süre artmaktadır. Artan işsizlik oranı uzun dönem Phillips eğrisindeki gibi doğal işsizlik oranına uzun dönemde geri dönmektedir. Yeni Keynesyenler ise enflasyona sebebiyet vermeyen, $\% 4$ ile $\% 6$ arasında seyretmesi gereken bu oranı nonaccelerating inflation rate of unemployment (NAIRU) olarak nitelendirmişlerdir. İşsizlik oranı NAIRU'nun altında olduğunda enflasyon oranı artma yönünde baskı yapmaktadır. 
OECD Ülkelerinde İşsizlik Histerisinin Ampirik Bir Analizi: Fourier Panel Durağanlık Testi

İkinci yaklaşımda ise Blanchard ve Summers (1986) işgücü piyasasında gerçekleşen katılıklar sebebiyle işsizlik oranındaki artışın zamanla kalıcı hale geldiğini ve şokların etkilerinin geçici olmadığını işsizlik histerisi hipotezi ile ileri sürmüşlerdir. Yazarlara göre ekonomide oluşan olumsuzluklar sebebiyle artan işsizlik oranları zamanla kalıcı olmakta ve bu noktada doğal ișsizlik oranı artık daha yüksek bir seviyede belirlenmektedir. Histeri etkisinin teorik açıklamaları yaygın olan geleneksel işsizlik oranının, gerçekleşen işsizlik oranı artarsa arttığını veya azalır ise azaldığını ileri sürmektedir (Darity ve Goldsmith, 1993: 55). İşsizlik histerisine göre işsizlik oranları geçmiş dönemdeki oranlardan etkilenmektedir. İşsizlik histerisi uzun dönemde yüksek işsizlik oranının ekonomide kalıcı ve ciddi bir problem olarak yer alacağını göstermektedir (Song ve Wu, 1998: 182). İşsizlikteki kalıcı artış çeşitli makroekonomik değişkenlerde oluşan olumsuzluklar nedeniyle gerçekleşebilir. Phelps ve Zoega (1998) reel faiz oranındaki artışın işsizliğin kalıcı bir şekilde yükselmesine sebebiyet verebileceğini belirtmişlerdir. Resesyon ortamında yüksek bir reel faiz oranı yatırımları dışlayarak işsizliğin artmasına neden olacaktır. İşsizlik sigortası ve işsizlerin yeteneklerini zamanla kaybetmesinden dolayı işsizlik oranlarındaki artış kalıcı bir hal alabilir. Aynı zamanda çalışan sendikalı işçiler, ücretlerin yüksek tutulmasını ve böylece yeni işçilerin istihdam edilmesini önleyebilir. Bu durumda dışarıda kalan ve zaman içerisinde verimi düşen yeni bir işçiyi istihdam etmek firma için eğitim maliyeti ve süre açısından dezavantajlıdır. Firma bu sebeple mevcut işçilerine daha fazla maaş ödemeyi kabul etmektedir. Ayrıca uzun süreli bir ekonomik krizde yüksek faiz oranları ve azalan sermaye stoku neticesiyle yatırımlar artmamaktadır. Bu sebeple işgücüne olan gereksinim azalmakta ve işsizlik oranları artmaktadır. Yüksek işsizlik, hükümet müdahalesi olmadan uzun vadede ciddi bir sorun olmaya devam edebileceği için işsizlik histerisi hipotezinin önemli politika sonuçları vardır. İşsizlik histerisi geçerli olduğu durumda hükümetler özellikle resesyon döneminde işsizlikle mücadelede daha aktif politikalar uygulamalıdır (Smyth, 2003: 181). $\mathrm{Bu}$ durumda genişletici politikalar ile enflasyona sebebiyet verilse de işsizlik kalıcı bir şekilde azaltılabilir (Mitchell, 1993: 1490).

Üçüncü yapısalcı yaklaşım ise şokların işsizlik üzerindeki etkilerini inceleyen tartışmaya yeni bir boyut kazandırmıştır. Pissarides (1992) ve Phelps (1994, 1999)'e göre ekonomik şoklar işsizlik üzerinde kalıcı etkilere sebebiyet vermektedir. Ancak bu durum uyarlama hızı yavaş olsa da uzun dönemde değişecektir. Yapısal kırılmalar ile birlikte durağan olan bir işsizlik serisi uzun dönemde işsizlik oranının eski seviyesine yavaş bir şekilde geri döneceğini göstermektedir. Ekonomide gerçekleşen resesyon veya genişleme dönemlerinde işsizlik doğal orandan sapsa da yapısal kırılmalar nedeni ile oluşan bu olgu er ya da geç ortadan kalkacaktır. Yapısalcıların bu yaklaşımında işsizlik histerisi hipotezi yapısal kırılmalar ile birlikte incelenen serinin birim kök içerdiğini, doğal işsizlik oranı hipotezi ise serinin yapısal kırılmalar ile birlikte durağan olduğunu ve bu nedenle kalıcı etkiler bırakan şokların etkilerinin uzun sürede ortadan kalkacağını belirtmektedir. Doğal oran hipoteziyapısalcı yaklaşıma karşı işsizlik histerisi hipotezinin geçerliliği birim kök veya durağanlık testleri ile sınanmaktadır. İstatistiksel olarak durağan olan bir serinin maruz kaldığ 1 olumlu veya olumsuz şoklar o seri üzerinde sadece geçici etkiler yaratmaktadır. Durağan seri zaman içerisinde çok büyük sapmalar göstermemektedir. Seri zaman içerisinde uzun dönem denge değerine yakınsamaktadır. Ancak birim kök içeren bir seri üzerinde şoklar kalıcı etkiler yaratmakta ve ilgili seri ortalama değerinden uzaklaşmaktadır. Örneğin işsizlik serisinin birim kök içerdiği bir ülkede işsizlik oranı ekonomik kriz ortamında belirli bir oranda arttığında kriz sonrasında bu oran kalıcı bir hale gelebilmektedir. Ancak durağan bir işsizlik serisine sahip olan ülkede krizin işsizlik oranı üzerinde kalıcı bir etkisi olmayacaktır. Bu nedenle durağanlık testleri ile işsizlik oranının stokastik özellikleri hakkında elde edilen bilgiler politika yapıcılarına yol gösterici nitelikte olabilmektedir. 
$\mathrm{Bu}$ çalışma OECD ülkelerinde işsizlik histerisi hipotezinin geçerliliğini yumuşak ve sert geçişleri dikkate alarak analiz etmektedir. İşsizlik oranı talep ve arz şoklarından doğrudan etkilenebilmektedir. Kısa süreli ekonomik sorunlar da işsizlik oranı üzerinde önemli değişimlere sebebiyet verebilmektedir. Keskin ve yumuşak yapısal değişimleri dikkate almadan gerçekleştirilen çalışmaların bulguları işsizlik oranlarının durağanlık özelliklerini tam olarak yansıtamayabilir. Bu açıdan çalışma Fourier panel durağanlık testi ile her iki türden yapısal kırılmaları dikkate alarak ve ülke bazında en fazla beş keskin yapısal kırılmayı analize dahil ederek mevcut literatüre katkı sağlamayı amaçlamaktadır.

Çalışmanın takip eden I. bölümünde Ekonomik Kalkınma ve İşbirliği Örgütü (OECD) ülkelerindeki işsizlik oranları karşılaştırılmıştır. II. bölümde işsizlik histerisini özellikle OECD ülkeleri ve Türkiye için sınayan ampirik çalışmalara yer verilmiş, III. bölümde ise kullanılan yöntem ve veri seti tanıtılmıştır. IV. bölümde yöntemden elde edilen sonuçlar sunulmuştur. Son olarak, sonuç bölümünde bulgulara göre OECD ülkelerinde işsizlik histerisinin geçerliliği tartışılmış ve çeşitli politika önerilerine yer verilmiştir.

\section{I- OECD ÜLKELERINNDE İŞSIZZLIK}

1960 yılında Fransa'da kurulan OECD, ekonomik ve politik ilişkileri geliştirmek için bir araya gelmiş ülkeler topluluğu olarak yer almaktadır. 20 kurucu ülke ile oluşturulan OECD'ye üye ülke sayısı günümüzde 36'ya ulaşmıştır. OECD ülkeleri 2008 finansal krizinden büyük ölçüde etkilenmişlerdir. Bu yıldan itibaren işsizlik oranları artmış, bazı ülkelerde ise işsizlik oranları kriz öncesi seviyeye geri döndürülememiş ve bu oranlar kalıcı hale gelmiştir.

\section{Şekil 1. OECD Ülkelerinde İssizlik Oranları (2006q1-2019q2, \%)}

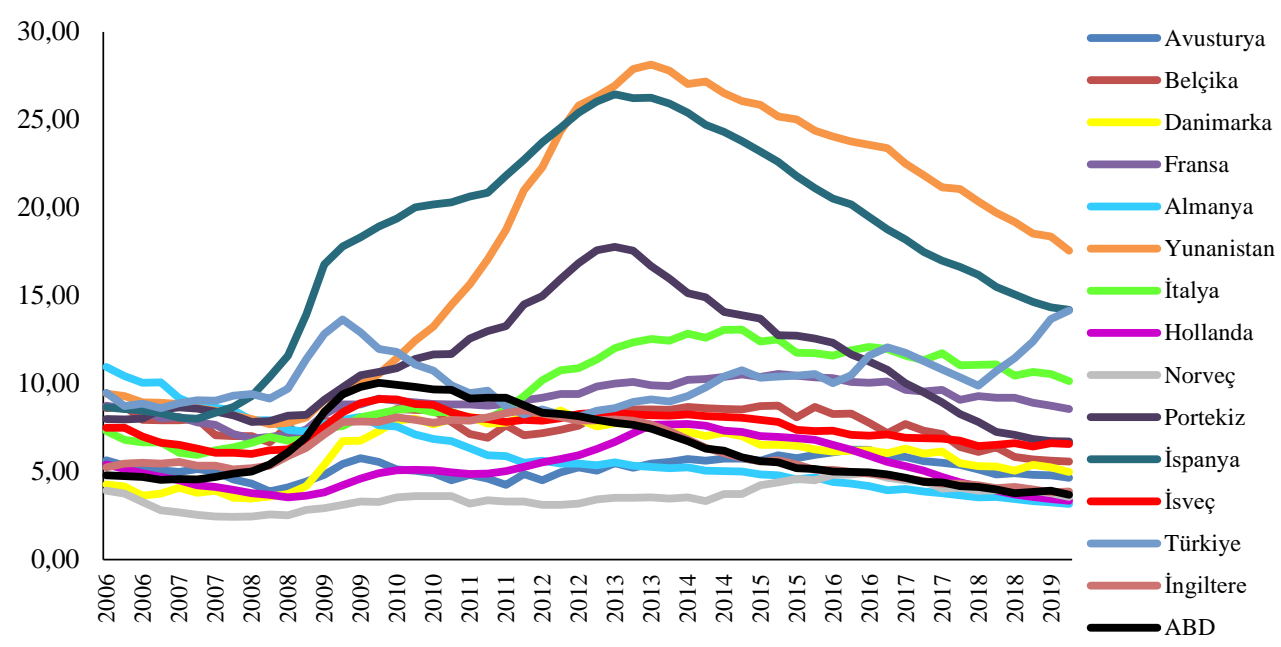

Kaynak: FRED, 2019.

Şekil 1, 2006'nın ilk çeyreğinden 2019'un ikinci çeyreğine kadar geçen süreçte 15 OECD ülkesinde gerçekleşen işsizlik oranlarını göstermektedir. 2006 yılında en düşük işsizlik oranı Norveç'te, en yüksek işsizlik oranı ise Almanya'dadır. Almanya'da yüksek seyreden bu işsizlik oranı yıllar itibariyle önemli ölçüde düşmüştür. 2008-2009 yılları arasında özellikle ABD, Danimarka, İsveç, Portekiz, İspanya ve Türkiye'de işsizlik oranlarının hızlı bir şekilde arttığı görülmektedir. Türkiye 2009 yılında \%13'lere ulaşan işsizlik oranını 2011-2014 arasında tek haneye indirmeyi başarabilmişstir. Ancak Yunanistan, Portekiz ve İspanya'da işsizlik oranları artmaya devam etmiş ve 2013 yılında en yüksek düzeyi görmüştür. 2009 
yılının sonunda Yunanistan, İspanya, İtalya ve Portekiz gibi Avrupa Birliği üyesi olan ülkelerin borçlarını ödeyememesi sebebiyle oluşan Avrupa Borç krizi bu üç ülkede işsizlik oranlarının hızla artmasında önemli bir etkendir. 2013 yılında ABD'nin varlık alımlarını azaltması bu ülkelerdeki işsizlik oranlarının daha da artmasına sebebiyet vermiştir. Bu yıldan itibaren ise İspanya, Yunanistan ve Portekiz'de işsizlik oranı önemli ölçüde azalmıştır. 2019 yılında 4 ülke hariç geriye kalan 11 OECD üyesi ülkede işsizlik oranları tek hanelidir. İtalya, Türkiye, İspanya ve Yunanistan'da işsizlik oranları çift haneli düzeydedir. Türkiye'de 20182019 arası bir yıllık süreçte işsizlik oranı yaklaşı \%4 artmıştır. OECD üyesi ülkelerde işsizlik oranları azalmakta veya yatay seyretmekte iken Türkiye'de oluşan bu durumu kur şokuna bağlamak mümkündür. 2018 Ocak ayında 1 dolar: 3,79TL olan nominal döviz kuru 10 Ağustos 2018 tarihinde 6,87TL'yi görerek Türk lirası dolar karşısında önemli ölçüde değer kaybetmiştir. Bu değer kaybının bir kısmının alınan çeşitli önlemlerle giderilmesine, yükselen faiz oranlarının ve enflasyonun düşmesine karşın işsizlik oranları artmaya devam etmiştir. Bu nedenle Türkiye için işsizlik çözülmesi gereken önemli bir makroekonomik sorun olarak yer almaktadir.

Şekil 2. OECD Ülkelerinde 2006 Yllı Birinci ve 2019 Yılı İkinci Çeyreği İssizlik Oranları

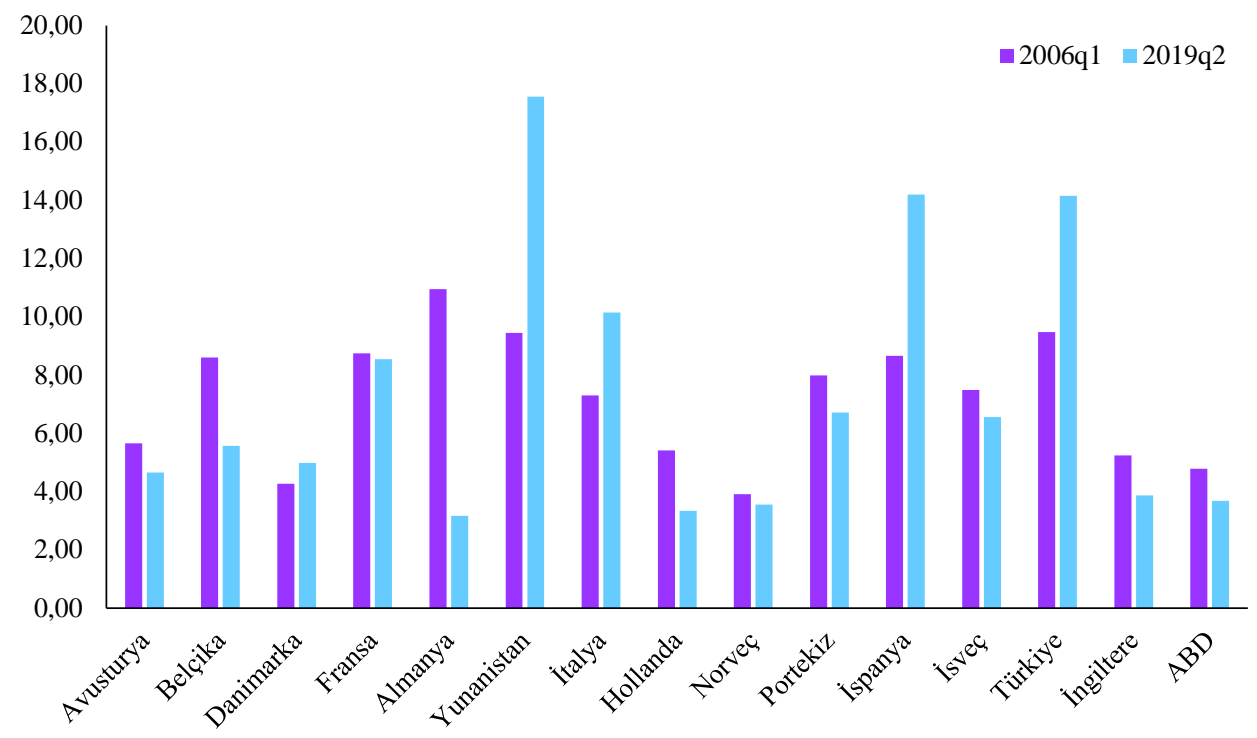

Kaynak: FRED, 2019.

Şekil 2'de 2006 yılının birinci çeyreği ve 2019 yılının ikinci çeyreğindeki işsizlik oranları 15 OECD ülkesi için gösterilmektedir. 10 OECD ülkesinde 2006 yılına göre 2019 yılında işsizlik oranları azalış göstermiştir. Almanya, Belçika ve Hollanda'da işsizlik ile mücadelede başarı sağlanmıştır. Yunanistan, İspanya ve Türkiye'de ise işsizlik 13 yılda önemli ölçüde artış göstermiştir. Danimarka ve İtalya'da işsizlik oranındaki artış bu üç ülkeye göre daha azdır. Şekil 1'de işsizlik oranlarının yapısal kırılmalar içerdiği ve şekil 2'de ise bu oranların zamanla önemli ölçüde değişebildiği görülmektedir. Bu nedenle işsizlik serilerinin özellikleri incelenirken yapısal kırılmaların dikkate alınması ile daha güvenilir sonuçlar elde edilebilir.

\section{II- LITERATÜR TARAMASI}

İşsizlik histerisi hipotezinin geçerliliği özellikle petrol krizinden itibaren artan işsizlik oranları için test edilmeye başlanmıştır. OECD ülkeleri için geçmişten günümüze konu ile 
ilgili birçok çalışma gerçekleştirilmiştir. Bu çalışmaların bir kısmında araştırmacılar zaman serisi, diğerlerinde ise panel veri yöntemlerini uygulamışlardır.

Panel veri ile gerçekleştirilen çalışmalardan; Camarero ve Tamarit (2004) 19 OECD ülkesinden Avusturya, Almanya, İtalya, Japonya, Norveç, Yeni Zelanda ve İsviçre'de, Camarero, Carrion-i-Silvestre ve Tamarit (2006) 19 OECD ülkesinden İtalya, Yeni Zelanda ve Kanada'da, Özcan (2012) 23 OECD ülkesinin 16'sında, Bekmez ve Ozpolat (2016) 17 OECD ülkesinden Avusturya, Belçika, Danimarka, Fransa, İtalya, Norveç, İspanya ve Türkiye'de ve Yalçınkaya ve Kaya (2017) ise 28 OECD ülkesinden Yeni Zelanda, Norveç, Meksika, İtalya, Kanada, İngiltere, Güney Kore, Danimarka, Fransa ve Belçika’da histerisi etkisi olduğunu belirtmişlerdir. Ancak Murray ve Papell (2000) ve Lee, Lee ve Chang (2009) ve Ener ve Arica (2011)'ya göre sırasıyla 17, 19 ve 15 OECD ülkesinin tamamı için işsizlik histerisi hipotezi geçerli değildir.

Zaman serisi ile gerçekleştirilen çalışmalardan; Mitchell (1993) 15 OECD ülkesinden sadece İtalya'da, Røed (1996) ABD hariç 16 OECD ülkesinin tamamında, Arestis ve Mariscal (1999) 26 OECD ülkesinden Avusturya, Kanada, Japonya ve ABD’de, Arestis ve Mariscal (2000) 22 OECD ülkesinden Avusturya, Fransa, İzlanda, İrlanda, Japonya, Hollanda, Norveç, İspanya, Yunanistan ve ABD'de, Papell, Murray ve Ghiblawi (2000) 16 OECD ülkesinden ABD’de, Yilanci (2008) 17 OECD ülkesinden Avusturalya, Avusturya, Kanada, Finlandiya, Almanya, Japonya, Lüksemburg, Norveç, Slovakya ve Türkiye’de, Gustavsson ve Österholm (2010) 17 OECD ülkesinden Avusturya, Finlandiya, İzlanda, İsrail, İtalya, Japonya ve İsveç’te, Chang (2011) 17 OECD ülkesinden Avusturalya, Belçika, Danimarka, Yunanistan, İrlanda, İtalya, Japonya, Hollanda, Portekiz, İspanya ve İngiltere'de, Fosten ve Ghoshray (2011) 6 OECD ülkesinin tamamında, Marques, Tadeu ve Troster (2017) 29 OECD ülkesinin tamaminda, Meng, Strazicich ve Lee (2017) 14 OECD ülkesinden Avusturya, İtalya, Japonya ve Portekiz'de ve Tiraşoğlu (2019) 32 OECD ülkesinden sadece Polonya'da işsizlik histerisi hipotezinin geçerli olduğunu tespit etmişlerdir. Bu çalışmaların aksine, Song ve Wu (1988) ve Lee ve Chang (2008) sirasıyla inceledikleri 15 ve 14 OECD ülkesinde histeri etkisinin olmadığını belirlemişlerdir.

Khraief, Shahbaz, Heshmati ve Azam (2020) ise zaman serisi ve panel veri analizini bir arada kullanarak, 29 OECD ülkesinin 25'inde histeri etkisinin olmadığını ifade etmişlerdir. Hem zaman serisi hem de panel veri analizi ile gerçekleştirilen çalışmalarda kullanılan yöntemler, dönem aralıkları ve işsizlik histerisi için nihai bulgular Tablo 1'de özetlenmiştir.

Tablo 1'de OECD ülkeleri için gerçekleştirilen 23 çalışmadan sadece 7'sinde işsizlik histerisi hipotezinin genel olarak kabul edildiği görülmektedir. Ülke sayısı (geçerlilik) sütununda parantez içerisindeki yer alan ifade histeri etkisinin kaç ülkede desteklendiğini göstermektedir. Histeri etkisinin genel sonuçlara göre reddedildiği iki çalışmalarda (Arestis ve Mariscal (2000); Yalçınkaya ve Kaya (2017)) 10 OECD ülkesinde histeri etkisi olduğu belirlenmiştir. İşsizlik histerisi hipotezini panelin veya incelenen ülkelerin tamamı için reddeden 4 çalışma mevcuttur. Geriye kalan 10 çalışmada en az bir tane OECD üyesi ülke için işsizlik histerisinin geçerli olduğu belirlenmiştir. Bu nedenle OECD ülkelerinde işsizlik histerisinin hâlâ tartışmalı bir konu olduğu görülmektedir.

Kullanılan veriler açısından literatür incelendiğinde, aylık veri kullanan iki güncel çalışmada (Marques, Tadeu ve Troster (2017), Tiraşoğlu (2019)) işsizlik histerisinin geçerli olduğu iddia edilmiştir. Bu durumda histeri etkisinin aylık, yıllık veya üçer aylık verilere göre değişiklik arz edeceği düşünülebilir. 
OECD Ülkelerinde İşsizlik Histerisinin Ampirik Bir Analizi: Fourier Panel Durağanlık Testi

Tablo 1. OECD Ülkeleri İçin İssizlik Histerisini Sinayan Ampirik Çalışmalar

\begin{tabular}{|c|c|c|c|c|}
\hline Yazar(lar) & Dönem & Yöntem & $\begin{array}{l}\text { Ülke sayısı/ } \\
\text { (Geçerlilik) }\end{array}$ & $\begin{array}{l}\text { İşsizlik } \\
\text { histerisi }\end{array}$ \\
\hline Mitchell (1993) & 1969q1-1991q3 & PP birim kök & $15(14)$ & $\checkmark$ \\
\hline Song ve Wu (1988) & 1970q1-1992q2 & $\begin{array}{l}\text { PP ve çeşitli panel } \\
\text { birim kök testleri }\end{array}$ & $15(0)$ & $\mathrm{X}$ \\
\hline Røed (1996) & 1970q1-1994q4 & ADF birim kök & $16(15)$ & $\checkmark$ \\
\hline Arestis ve Mariscal (1999) & 1960q1-1997q2 & LP birim kök & $26(4)$ & $\mathrm{X}$ \\
\hline Arestis ve Mariscal (2000) & 1960q1-1997q3 & PP birim kök & $22(10)$ & $\mathrm{X}$ \\
\hline Murray ve Papell (2000) & $1955-1990$ & Panel birim kök testi & $19(0)$ & $\mathrm{X}$ \\
\hline $\begin{array}{l}\text { Papell, Murray ve } \\
\text { Ghiblawi (2000) }\end{array}$ & $1955-1997$ & ZA birim kök & $16(1)$ & $\mathrm{X}$ \\
\hline $\begin{array}{l}\text { Camarero ve Tamarit } \\
\text { (2004) }\end{array}$ & $1956-2001$ & $\begin{array}{l}\text { SURADF panel birim } \\
\text { kök }\end{array}$ & $19(7)$ & $\mathrm{X}$ \\
\hline $\begin{array}{l}\text { Camarero, Carrion-i- } \\
\text { Silvestre ve Tamarit } \\
\text { (2006) }\end{array}$ & $1956-2001$ & $\begin{array}{l}\text { Panel KPSS } \\
\text { durağanlık }\end{array}$ & $19(3)$ & $\mathrm{X}$ \\
\hline Lee ve Chang (2008) & $1855-2004$ & LS birim kök & $14(0)$ & $\mathrm{X}$ \\
\hline Yilanci (2008) & 1970q1-2008q4 & KSS birim kök & $17(10)$ & $\checkmark$ \\
\hline Lee, Lee ve Chang (2009) & $1960-2004$ & Panel LM birim kök & $19(0)$ & $\mathrm{X}$ \\
\hline $\begin{array}{l}\text { Gustavsson ve Österholm } \\
\text { (2010) }\end{array}$ & 1948q1-2005q4 & $\begin{array}{l}\text { Örneklem dişı öngörü } \\
\text { yöntemi }\end{array}$ & $17(7)$ & $\mathrm{X}$ \\
\hline Chang (2011) & $1960-2009$ & $\begin{array}{l}\text { Zaman serisi-Fourier } \\
\text { KPSS }\end{array}$ & $17(6)$ & $\mathrm{X}$ \\
\hline Ener ve Arica (2011) & $1985-2008$ & $\begin{array}{l}\text { Panel CADF, } \\
\text { SURADF, CBL }\end{array}$ & $15(0)$ & $X$ \\
\hline Fosten ve Ghoshray (2011) & $1855-2008$ & $\begin{array}{l}\text { Rejim değişikliğine } \\
\text { izin veren birim kök }\end{array}$ & $6(6)$ & $\checkmark$ \\
\hline Özcan (2012) & 1971-2006 & Panel LM birim kök & $23(16)$ & $\checkmark$ \\
\hline Bekmez ve Ozpolat (2016) & 1991-2014 & Panel LM birim kök & $17(8)$ & $\mathrm{X}$ \\
\hline $\begin{array}{l}\text { Marques, Tadeu ve Troster } \\
\text { (2017) }\end{array}$ & $\begin{array}{l}2000 \mathrm{~m} 1- \\
2015 \mathrm{~m} 10 \\
\end{array}$ & $A D F-G L S$ & $29(29)$ & $\checkmark$ \\
\hline $\begin{array}{l}\text { Meng, Strazicich ve Lee } \\
\text { (2017) }\end{array}$ & 1983q1-2013q3 & $\begin{array}{l}\text { Zaman serisi- Fourier- } \\
L M, \text { Fourier-RALSLM }\end{array}$ & $14(4)$ & $\mathrm{X}$ \\
\hline $\begin{array}{l}\text { Yalçınkaya ve Kaya } \\
\text { (2017) }\end{array}$ & $1980-2015$ & $\begin{array}{l}\text { Panel CADF ve } \\
\text { SURADF }\end{array}$ & $28(10)$ & $X$ \\
\hline Tiraşoğlu (2019) & $\begin{array}{l}2005 \mathrm{~m} 1- \\
2017 \mathrm{~m} 7\end{array}$ & $\begin{array}{l}\text { Zaman serisi- } \\
\text { nonlinear Fourier } \\
\text { birim kök }\end{array}$ & $32(31)$ & $\checkmark$ \\
\hline $\begin{array}{l}\text { Khraief, Shahbaz, } \\
\text { Heshmati ve Azam (2020) }\end{array}$ & $1980-2013$ & $\begin{array}{l}\text { ESTAR birim kök } \\
\text { testi }\end{array}$ & $29(4)$ & $\mathrm{X}$ \\
\hline
\end{tabular}

Not: Yöntem kısmında italik yazılanlar yapısal kırılmaları dikkate alan metotlardır. LP: Lumsdaine-Papell, PP: Phillips-Perron. ADF: Augmented Dickey-Fuller. ZA: Zivot-Andrews. LS: Lee-Strazicich

Yapısal kırılmaları dâhil etmeden yapılan analizlerde birim kök hipotezi daha nadir reddedilebilir ve bu durum histerisi etkisinin hatalı bir şekilde daha fazla görülmesine sebebiyet verebilir (Fosten ve Ghoshray, 2011: 949). İşgücü piyasası ülkenin nüfusu ve ekonomik durumuna göre değişmekte ve kırılmalar ani veya doğrusal bir şekilde gerçekleşmemektedir. İşgücü piyasasında kadınların işgücüne dâhil olması, eğitim, sendikalaşma, fiyat katılıkları gibi çeşitli esnekliği değiştirecek faktörlerin etkisi genellikle yumuşak geçiş şeklinde oluşmaktadır (Ağazade, 2016: 31). Bu nedenle işsizlik histerisini sınarken doğrusal olmayan ve yumuşak geçişleri dikkate alan yeni geliştirilmiş birim kök 
veya durağanlık testleri ile daha güvenilir bulgular elde edilebilir. Literatürde 12 çalışma analize yapısal kırılmaları dâhil etmiştir. Bu çalışmalardan sadece üç tanesi yumuşak geçişleri dikkate almıştır. Chang (2011) histeri etkisinin OECD ülkeleri için geçerli olmadığını belirtirken aksine Meng, Strazicich ve Lee (2017) ve Tiraşoğlu (2019) işsizlik histerisinin OECD ülkelerinde var olduğunu ifade etmektedirler. Gerçekleştirilen üç çalışmada da zaman serisi analizinde Fourier fonksiyonları modellemeye dâhil edilmiştir. Bu çalışma bahsi geçen çalışmalardan farklı olarak Fourier CBL panel durağanlık testi uygulayarak OECD ülkelerinde işsizlik oranlarını analiz etmektedir. Çalışma 15 OECD ülkesinde işsizlik histerisi hipotezinin geçerliliğini hem yumuşak hem de sert geçişleri dikkate alarak sınamaktadır. Bu yönüyle çalışmanın mevcut literatüre katkı sağlaması beklenmektedir.

\section{III- VERİ SETİ VE YÖNTEM}

\section{A- Veri Seti}

15 OECD üyesi ülkede (Avusturya, Belçika, Danimarka, Fransa, Almanya, İtalya, Hollanda, Norveç, Portekiz, İspanya, İsveç, İngiltere ve ABD) işsizlik histerisinin geçerliliğinin sınandığı bu çalışmada kullanılan, 1991 Ocak- 2019 Nisan aralığını kapsayan üçer aylık işsizlik verileri ABD Merkez Bankası'nın veri tabanından (FRED, 2019) elde edilmiştir. 1564 yaş aralığındaki işsizlik oranı verileri ABD Merkez Bankası tarafından mevsimsellikten arındırılmıştır. Çalışmada işsizlik histerisinin analizi için Fourier CBL durağanlık testi kullanılmıştır. Bu test uygulanırken her bir ülke için yüksek zaman boyutuna ihtiyaç duyulmaktadır. Dolayısıyla çalışmada 20 kurucu OECD üyesi ülke arasından 50 üzeri gözleme sahip mevcut verileri bulunan 15 ülke seçilmiştir. Bu ülkelere ait verilerin istatistiksel özellikleri Tablo 2'de gösterilmektedir.

Tablo 2. Serilere Ait Tanımlayıcı Istatistikler

\begin{tabular}{lrrrrrc}
\hline Ülkeler & Ortalama & Ortanca & Eğiklik & Basıklık & Jarque-Bera & Olasılık değeri \\
\hline Avusturya & 5,1997 & 5,1385 & $-0,1789$ & 2,4388 & 0,9967 & 0,6075 \\
\hline Belçika & 7,6595 & 7,8651 & $-0,7511$ & 2,6834 & 5,3031 & 0,0705 \\
\hline Danimarka & 6,1520 & 6,2924 & $-0,3541$ & 1,8422 & 4,1449 & 0,1259 \\
\hline Fransa & 9,1195 & 9,1093 & $-0,5353$ & 2,6354 & 2,8778 & 0,2372 \\
\hline Almanya & 6,0239 & 5,4472 & 0,6058 & 2,4454 & 3,9954 & 0,1356 \\
\hline Yunanistan & 18,100 & 19,459 & $-0,1966$ & 1,4885 & 5,4885 & 0,0643 \\
\hline İtalya & 9,7838 & 10,505 & $-0,2217$ & 1,5554 & 5,1378 & 0,0766 \\
\hline Hollanda & 5,2883 & 5,0631 & 0,3987 & 2,0393 & 3,5069 & 0,1732 \\
\hline Norveç & 3,5667 & 3,5396 & 0,1937 & 2,4635 & 0,9854 & 0,6110 \\
\hline Portekiz & 11,219 & 10,829 & 0,4431 & 2,0435 & 3,8252 & 0,1477 \\
\hline İspanya & 18,146 & 19,157 & $-0,4050$ & 2,0494 & 3,5091 & 0,1730 \\
\hline İsveç & 7,4722 & 7,4878 & 0,0354 & 1,8817 & 2,8253 & 0,2435 \\
\hline Türkiye & 10,264 & 9,9784 & 0,7292 & 2,8123 & 4,8644 & 0,0878 \\
\hline İngiltere & 6,1566 & 5,6162 & 0,1299 & 1,5508 & 4,8776 & 0,0873 \\
\hline ABD & 6,3708 & 5,5653 & 0,4692 & 1,7425 & 5,5397 & 0,0627 \\
\hline Panel & 8,7016 & 7,7845 & $-0,2541$ & 2,4298 & 3,7483 & 0,1462 \\
\hline \hline
\end{tabular}

Tablo 2'de gösterilen değerlere göre işsizlikte en yüksek ortalama sırasıyla İspanya, Yunanistan, Türkiye ve Portekiz'dedir. Bu ülkelerdeki işsizlik oranı mevcut veri için \% 10 'un üzerindedir. Geriye kalan 14 ülkede işsizlik oranlarının ortalamaları tek hanelidir. İşsizlik oranlarındaki en düşük ortalama ve ortancanın Norveç’te olduğu görülmektedir. En yüksek 
ortanca sırasıyla Yunanistan, İspanya ve Portekiz'dedir. Sıfıra yakın eğiklik ve ikiye yakın basıklık değerleri 15 ülkenin tamamında işsizlik oranının normal dağılıma sahip olduğunu göstermektedir. Ayrıca Jarque-Bera test istatistikleri ve olasılık değerleri normal dağılımı belirten sıfır hipotezinin \%5 güven aralığında reddedilemediğini belirtmektedir. Diğer bir değişle, serilerin zaman içerisindeki değerleri sapmalar olsa da ortalamaya yakın seyretmektedir. Serilerin normal dağılmamasının oluşturabileceği tahminlerde sapma problemi bu 15 ülkenin işsizlik serisi için geçerli değildir. Böylece çalışmada normal dağılıma sahip işsizlik oranları ile daha etkin tahminlerde bulunulabilir. Panelin tamamı için de işsizlik oranı normal dağılıma sahiptir. Panel ortalaması 8,7, ortancası ise 7,78'dir. Türkiye, İspanya, Portekiz, İtalya, Yunanistan, Fransa ve Belçika' da işsizlik oranı ortalaması ilgili dönem için panel ortalamasından yüksektir.

\section{B- Yatay Kesit Bağımlılığı ve Homojenlik Testleri}

Panel veri analizinde incelenen yatay kesitlerin herhangi birinde oluşan bir şok diğer bir kesiti etkileyebilmektedir. Günümüzde özellikle küreselleşen dünya düzeninde bir ülkede oluşan ekonomik, siyasi bir kriz, talep veya arz şoku, fiyatlardaki artış veya azalışlar diğer ülkelere de yansıyabilmektedir. Yatay kesit bağımlılı̆̆ olarak nitelendirilen bu durumun varlığı, Breusch ve Pagan (1980) tarafından Lagrenge çarpanı (LM) ve Pesaran (2015) tarafindan geliştirilen CD testi ile incelenmiştir. LM testinin sıfır hipotezi yatay kesit bağımlılığı olmadığını ifade ederken, CD testinin sıfır hipotezi zayıf bir yatay kesit bağımlılığın olduğunu ve bu bağımlılı̆̆ın T ve $\mathrm{N}$ arttığında giderilebileceğini belirtmektedir. Her iki testin alternatif hipotezi yatay kesitler arasında güçlü bir bağlantının olduğunu ima etmektedir.

Zaman serisi analizinin aksine panel veri analizinde hem birimler arası farklılıklar hem de birim özellikleri aynı anda belirtilebilmektedir (Yerdelen Tatoğlu, 2013: 10). Panel veriyi oluşturan her bir yatay kesit veya ülkenin aynı özelliklere sahip olması homojenlik, farklı özelliklere sahip olması ise heterojenlik olarak adlandırılmaktadır. Bu çalışmada incelenen panel verinin homojenliği Pesaran ve Yamagata (2008)'nın geliştirdikleri delta $(\widetilde{\Delta})$ ve düzeltilmiş delta $\left(\widetilde{\Delta}_{\text {adj }}\right)$ testleri ile analiz edilmiştir. Her iki testle de sıfır hipotezi reddedildiğinde panelin heterojen bir yapıya sahip olduğuna karar verilmektedir. Analiz gerçekleştirilecek olan panel veride yatay kesit bağımlılığı ve heterojenlik varsa her iki olguyu da dikkate alan testler kullanılmalıdır.

\section{C- Fourier Panel Durağanlık Testi}

Zaman içerisinde gerçekleşen şokların değişkenler üzerindeki etkilerinin kalıcı mı yoksa geçici mi olduğu birim kök veya durağanlık testleri ile belirlenmektedir. Seriler durağan ise şokların etkileri geçicidir. Sıfir hipotezi incelenen serilerde birim kök olduğunu belirten testler birim kök testi, benzer şekilde sıfır hipotezi serilerin durağan olduğunu ifade eden testler ise durağanlık testi olarak adlandırılabilir (Becker, Enders ve Lee, 2006: 407).

Dickey ve Fuller (1981) tarafından geliştirilmiş öncü genelleştirilmiş Dickey Fuller (ADF) birim kök testi ile değişkenlerin stokastik özellikleri yaygın olarak sınanmaya başlanmıştır. Bu testte sıfır hipotezi incelenen serinin birim kök içerdiğini ifade etmektedir. Kwiatkowski, Phillips, Schmidt, ve Shin (1992)'in geliştirmiş oldukları ve bu yazarların baş harfleri ile nitelendirilen KPSS durağanlık testinde ise sıfır hipotezi serinin durağan olduğunu belirtmektedir. Her iki testte de yapısal kırılmalar ihmal edilmektedir. Makroekonomik seriler ekonomik kriz, politika belirsizliği, arz ve talep şokları gibi çeşitli ekonomik dalgalanmalardan etkilenmektedir. Bu tür yapısal değişimlerin incelenen serinin özellikleri belirlenirken dikkate alınması gerekmektedir. Perron (1989) yapısal kırılmalar dikkate alınmadan gerçekleştirilen analizlerde makroekonomik serilerin durağanlık düzeylerinin 
yanlış bir şekilde belirlenebileceğini belirtmiştir. Zivot ve Andrews (1992) içsel olarak bir kırılmaya izin veren bir birim kök testi geliştirmişlerdir. Bu birim kök testinden sonra literatürde bir ve birden fazla yapısal kırılmaya izin veren çeşitli birim kök testleri geliştirilmiştir. Ancak tüm bu birim kök testlerinde yapısal kırılmalar sert geçişli ve sayısı belirli olarak yer almaktadır. Bu durum yumuşak geçişlerin ve olası kısa süreli yapısal değişimlerin etkilerinin ihmaline sebebiyet verebilmektedir.

Becker, Enders ve Lee (2006) KPSS testine Gallant (1981) tarafından geliştirilmiş Fourier fonksiyonlarını ekleyerek, zamanı, yapısı ve sayısı belli olmayan yumuşak geçişlerin de seriler üzerindeki etkilerinin analize dâhil edildiği Fourier-KPSS (FKPSS) durağanlık testini oluşturmuşlardır. Bu testte kullanılan sırasıyla birikimli frekanslı ve tek frekanslı Fourier fonksiyonları denklem 1 ve 2 'de gösterilmektedir.

$$
\begin{aligned}
& \alpha(\mathrm{t}) \cong \varphi_{0}+\sum_{\mathrm{k}=1}^{\mathrm{n}} \mathrm{u}_{1, \mathrm{i}} \sin \left(\frac{2 \pi \mathrm{k}_{\mathrm{i}} \mathrm{t}}{\mathrm{T}}\right)+\sum_{\mathrm{k}=1}^{\mathrm{n}} \mathrm{p}_{2, \mathrm{i}} \cos \left(\frac{2 \pi \mathrm{k}_{\mathrm{i}} \mathrm{t}}{\mathrm{T}}\right) \\
& \alpha(\mathrm{t}) \cong \varphi_{0}+\mathrm{a}_{1, \mathrm{i}} \sin \left(\frac{2 \pi \mathrm{kt}}{\mathrm{T}}\right)+\mathrm{b}_{2, \mathrm{i}} \cos \left(\frac{2 \pi \mathrm{kt}}{\mathrm{T}}\right)
\end{aligned}
$$

Denklemlerde $\alpha(\mathrm{t})$ sabit terimin zamanla değişmediği varsayımının terk edildiğini göstermektedir. Birikimli frekanslı Fourier fonksiyonunun yer aldığı denklem 1'de T gözlem sayısını, n T/2'den az olan frekans sayısını, $\pi$ pi değerini, $k$ belirli bir frekansı, $\mathrm{u}_{1, i}, \mathrm{p}_{2, \mathrm{i}}, \mathrm{a}_{1, \mathrm{i}}$ ve $b_{2, i}$ katsayıları belirtmektedir. Denklem 2'de $n=1$ olduğundan dolayı toplam fonksiyonları yer almamaktadır. Carrion-i-Silvestre, Del Barrio-Castro ve López-Bazo (2005) KPSS testine dayalı, sıfır hipotezi serinin durağan olduğunu belirten, her bir yatay kesit için durağanlık hakkında bilgi veren ve sert geçişlere izin veren CBL durağanlık testini literatüre kazandırmışlardır. Bu test aynı zamanda panel veride yatay kesit bağımlılığını dikkate almaktadır. CBL durağanlık testi için oluşturulan eşitlik denklem 3 'te gösterilmektedir.

$\mathrm{y}_{\mathrm{i}, \mathrm{t}}=\alpha_{\mathrm{i}}+\sum_{\mathrm{k}=1}^{\mathrm{m}_{\mathrm{i}}} \delta_{\mathrm{i}, \mathrm{k}} \mathrm{DU}_{\mathrm{i}, \mathrm{k}, \mathrm{t}}+\mathrm{e}_{\mathrm{i}, \mathrm{t}}$

Sadece sabitli model için oluşturulan denklem 3'te m uygun yapısal kırılma sayısını, $\alpha_{i}$ sabit terimi ve DU keskin geçişlerin belirlendiği kukla değişkeni ifade etmektedir. Bu kukla değişkenin iki duruma göre aldığı değerler denklem 4 'te gösterilmektedir.

$\mathrm{t}>\mathrm{TB}_{\mathrm{k}}$ durumunda 1 , diğer durumlarda 0

Denklemde $\mathrm{TB}_{\mathrm{k}}^{\mathrm{i}} \mathrm{k}$ tarihte bir yatay kesit için oluşan kırılmayı göstermektedir. $\delta_{\mathrm{i}, \mathrm{k}}$ yapısal kırılmaların paneli oluşturan her bir kesit için farklı etkilerini göstermektedir. CBL testi paneldeki her bir yatay kesit için farklı tarihte yapısal kırılmaları analize dâhil ederek ilgili serinin durağanlığı sınamayı sağladığından dolayı yatay kesit bağımlılığını dikkate almaktadır. Bu testte çok sayıda sert geçişlere izin verilmektedir. Bahmani-Oskooee, Chang ve $\mathrm{Wu}(2014,2015)$ ise bu durağanlık testine Fourier fonksiyonlarını ekleyerek keskin geçişlerin yanında yumuşak geçişleri de analize dâhil etmişlerdir. Yazarlar böylece zamanı, yapısı ve sayısı belirli olmayan yapısal kırılmaların etkilerinin dikkate alınmasını sağlamışlardır. Denklem 1, denklem 3'e yerleştirilerek Fourier-CBL durağanlık testi aşağıdaki gibi elde edilmektedir.

$\mathrm{y}_{\mathrm{i}, \mathrm{t}}=\alpha_{\mathrm{i}}+\sum_{\mathrm{k}=1}^{\mathrm{m}+1} \delta_{\mathrm{i}, \mathrm{k}} \mathrm{DU} \mathrm{i}_{\mathrm{i}, \mathrm{k}, \mathrm{t}}+\mathrm{a}_{1, \mathrm{i}} \sin \left(\frac{2 \pi \mathrm{kt}}{\mathrm{T}}\right)+\mathrm{b}_{2, \mathrm{i}} \cos \left(\frac{2 \pi \mathrm{kt}}{\mathrm{T}}\right)+\mathrm{e}_{\mathrm{i}, \mathrm{t}}$ 
Birden fazla frekans birleşeni kullanmak serbestlik derecenin azalmasına ve varyansın yüksek olmasına sebebiyet vermektedir (Enders ve Lee, 2012: 197). Modelde $n=1$ olarak tek frekansın dikkate alınması ile bu sorunlar önlenebilir. Bu nedenle denklem 5 'te yer alan Fourier-CBL testinde, denklem 1'de yer alan tek frekanslı Fourier fonksiyonları kullanılmıştır. Tek frekanslı bu testte $\mathrm{t}$ trendi, T gözlem sayısını, m yapısal kırılma tarihlerini, $\mathrm{k}$ belirli bir frekansı ifade etmektedir. CBL testinde olduğu gibi DU keskin yapısal kırılmaların yakalandığı kukla değişkeni ifade etmektedir. $a_{1, i}$ ve $b_{2, i}$ ise yumuşak geçişlerin yakalandığı katsayıları belirtmektedir. Bu kukla değişkenin iki duruma göre aldığı değerler denklem 6'da gösterilmektedir.

$\mathrm{TB}_{\mathrm{k}-1}^{\mathrm{i}}<\mathrm{t}<\mathrm{TB}_{\mathrm{k}}^{\mathrm{i}}$ durumunda 1 , diğger durumlarda 0

Fourier-CBL durağanlık testi iki aşamadan oluşmaktadır. İlk olarak keskin geçişler (m) belirlenmekte ve uygun frekans (k) tespit edilmektedir. İkinci aşamada ise denklem 7 ile lineer olmayan bileşenlerin gerekliliği sınanmaktadır.

$\mathrm{F}\left(\mathrm{k}^{*}\right)=\frac{\left(\mathrm{KKT}_{0}-\mathrm{KKT}_{1}\left(\mathrm{k}^{*}\right)\right) / 2}{\mathrm{KKT}_{1}\left(\mathrm{k}^{*}\right) /(\mathrm{T}-\mathrm{q})}$

Denklemde $\mathrm{KTT}_{0}$ ve $\mathrm{KTT}_{1}$ sirasiyla denklem 5'te lineer olmayan terimlerin varlığ 1 ve yokluğu ile elde edilen kısıtsız ve kısıtlı kalıntılar kareler toplamlarını ifade etmektedir. İlk aşamada uygun kırılma tarihleri $(\mathrm{m})$ belirlendikten sonra, ikinci aşamada uygun frekans $\mathrm{k}$ tespit edilmektedir. KTT değerini en küçük yapan $\mathrm{k}^{*}$ hesaplandıktan sonra $\mathrm{k}=\mathrm{k}^{*}$ olacak şekilde denklem 5 tekrar tahmin edilmektedir. Becker, Enders ve Lee (2006: 391)'nin önerisi üzerine $\mathrm{KKT}_{0}$ ve $\mathrm{KTT}_{1}$ elde edildikten sonra denklem 7 tahmin edilerek F-istatistiği tespit edilmektedir. F-istatistiği hesaplanan tablo kritik değerlerinden büyük olduğunda lineer olmayan sinüs ve kosinüs terimlerinin denklemde yer almaması gerektiğini ifade eden sıfir hipotezi reddedilmekte ve böylece Fourier fonksiyonlarının incelenen serinin durağanlık özellikleri sınanırken analize dâhil edilmesinin gerekli olduğuna karar verilmektedir. Fistatistiği tablo kritik değerinden küçük olduğunda ve sıfır hipotezi reddedilemediğinde ise Fourier fonksiyonları analize dâhil edilmeden lineer CBL durağanlık testinin kullanılması ile daha güvenilir bulgular elde edilebilir. Fourier CBL durağanlık testinde sıfır hipotezi incelenen serilerin keskin ve yumuşak geçişlerle birlikte durağan olduğunu ifade etmektedir. F-istatistiği ile lineer olmayan fonksiyonların kullanılmasına karar verildiğinde ve Fourier CBL testinde sıfır hipotezi reddedilmediğinde, bilinen ve bilinmeyen yapısal kırılmaların etkileri de göz önünde bulundurularak incelenen serinin durağan olduğu tespit edilmektedir.

\section{IV- AMPÍRIK BULGULAR}

Çalışmada ilk olarak panel verideki yatay kesitler arasındaki bağımlılığın ve homojenliğin tespiti için çeşitli testler kullanılmıştır. Bu testlere ait bulgular tablo 3 'te yer almaktadır. Tabloda gösterilen bulgulara göre hem LM hem de CD testlerinde sıfır hipotezi \%1 anlamlılık düzeyinde reddedildiği için ülkeler arasında yatay kesit bağımlılı̆̆ 1 olduğuna karar verilmiştir. $\mathrm{Bu}$ nedenle işsizlik oranlarının ülkeler arasında etkileşim içerisinde olduğu belirlenmiştir. Ayrıca gerçekleştirilen delta ve düzeltilmiş delta testleri ile de panelin heterojen olduğu belirlenmiştir. Dolayısıyla hem yatay kesit bağımlılığı hem de heterojenliği dikkate alan panel durağanlık testi kullanılmıştır. Panel Fourier-CBL testini gerçekleştirmek için ilk olarak F-istatistiği ile trigonometrik fonksiyonlara gerek duyup duyulmadığı belirlenmiş ve uygun frekans seçimi yapılmıştır. 
Sosyal Güvenlik Dergisi • Journal of Social Security • 2020/1

Tablo 3. Yatay Kesit Bă̆ımlılı̆̆l ve Homojenlik Testleri

\begin{tabular}{lcccc}
\hline Testler & LM & CD & $\widehat{\Delta}$ & $\widehat{\Delta}_{\text {adj }}$ \\
\hline Test istatistiği & 150,659 & 72,212 & 11.223 & 12.452 \\
\hline Olas1lık değeri & 0,002 & 0,000 & 0,000 & 0,000 \\
\hline
\end{tabular}

Tablo 4’te gösterilen sonuçlara göre F-istatistiği Norveç için \%5 ve geriye kalan tüm ülkeler için \%1 anlamlılık düzeyinde tablo kritik değerlerinden büyüktür. Bu sebeple serilerin durağanlığı sınanırken doğrusal olmayan terimler de analize dâhil edilerek yumuşak geçişlerin dikkate alınması gerekmektedir.

Tablo 4. Uygun Frekans Seçimi ve F-İstatistiği

\begin{tabular}{|c|c|c|c|c|c|}
\hline Ülkeler & F-İstatistiği & $\% 1$ & $\% 5$ & $\% 10$ & $\begin{array}{l}\text { Uygun } \\
\text { Frekans }\end{array}$ \\
\hline Avusturya & $75,819 * * *$ & 5,402 & 3,346 & 2,565 & 1 \\
\hline Belçika & $186,969 * * *$ & 5,173 & 3,250 & 2,453 & 1 \\
\hline Danimarka & $181,698 * * *$ & 5,121 & 3,182 & 2,392 & 1 \\
\hline Fransa & $200,662^{* * *}$ & 5,181 & 3,209 & 2,461 & 1 \\
\hline Almanya & $10,811^{* * *}$ & 5,376 & 3,318 & 2,501 & 4 \\
\hline Yunanistan & $246,152 * * *$ & 4,795 & 3,054 & 2,259 & 1 \\
\hline İtalya & $83,088 * * *$ & 5,081 & 3,251 & 2,432 & 1 \\
\hline Hollanda & $175,105^{* * *}$ & 4,965 & 3,131 & 2,385 & 1 \\
\hline Norveç & $4,670 * *$ & 5,103 & 3,256 & 2,453 & 3 \\
\hline Portekiz & $889,938 * * *$ & 5,240 & 3,184 & 2,427 & 1 \\
\hline İspanya & $1084,664^{* * *}$ & 5,129 & 3,173 & 2,438 & 1 \\
\hline İsveç & $68,137 * * *$ & 5,023 & 3,277 & 2,458 & 3 \\
\hline Türkiye & $11,865^{* * *}$ & 4,986 & 3,174 & 2,418 & 5 \\
\hline İngiltere & $248,429 * * *$ & 5,282 & 3,280 & 2,525 & 1 \\
\hline $\mathrm{ABD}$ & $281,146^{* * *}$ & 4,909 & 3,237 & 2,395 & 1 \\
\hline
\end{tabular}

Not: Uygun frekans en küçük KKT’ye göre belirlenmiştir. *** \%1 ve ** \%5 anlamlllık düzeyinde modelin doğrusal olmayan fonksiyonları içermemesi gereken sıfır hipotezinin reddedildiğini göstermektedir.

Yapısal kırılma tarihleri belirlendikten sonra serilerin fiili ve tahmini zaman yolları çizilmiştir. Fourier fonksiyonları ile serilerin etkileşimi her bir ülke için Şekil 3'te gösterilmektedir. 
OECD Ülkelerinde İşsizlik Histerisinin Ampirik Bir Analizi: Fourier Panel Durağanlık Testi

Şekil 3. Serilere Ait Gerçekleşen ve Tahmin Edilen Zaman Yolu
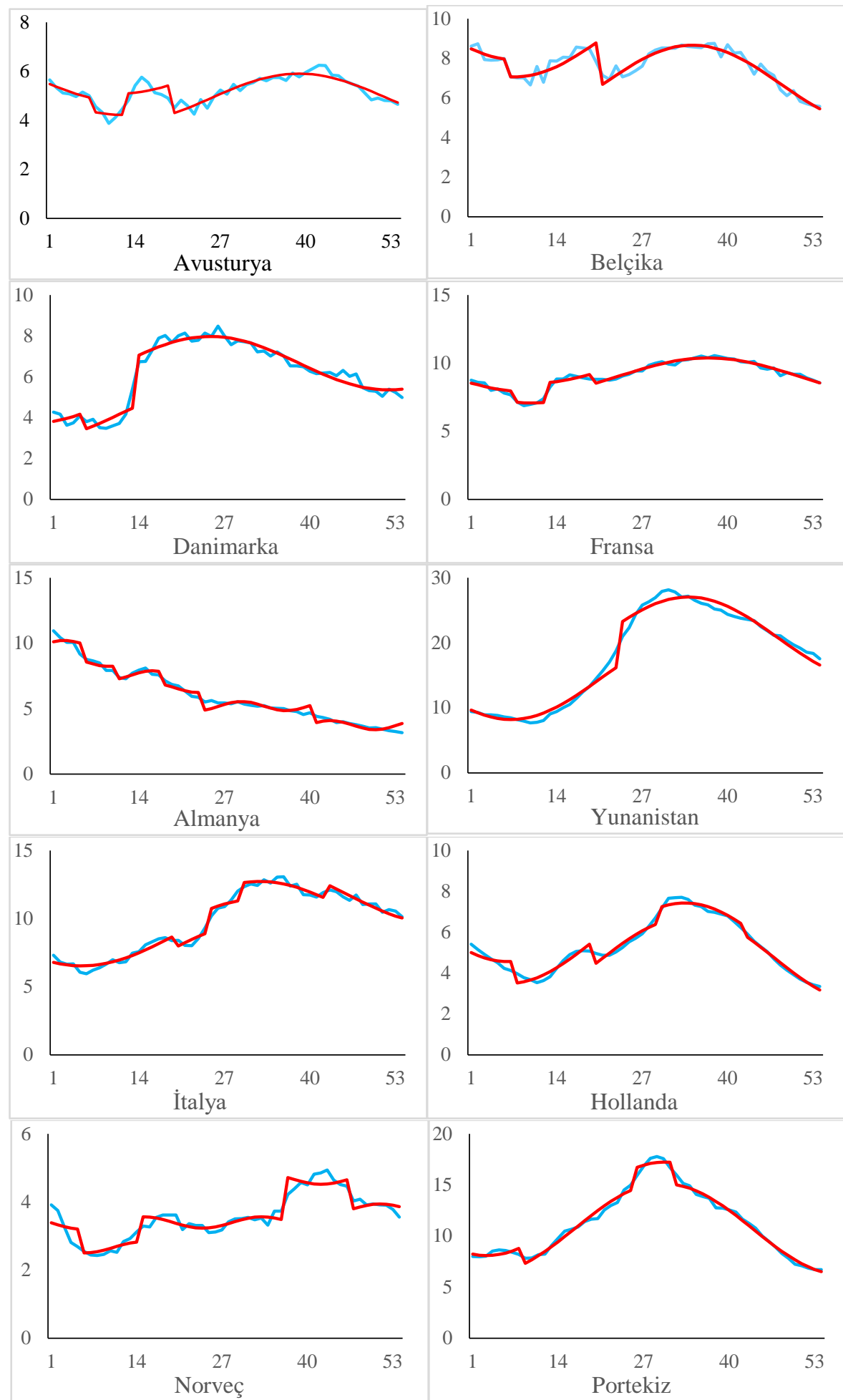
Şekil 3. Serilere Ait Gerçekleşen ve Tahmin Edilen Zaman Yolu (Devamı)
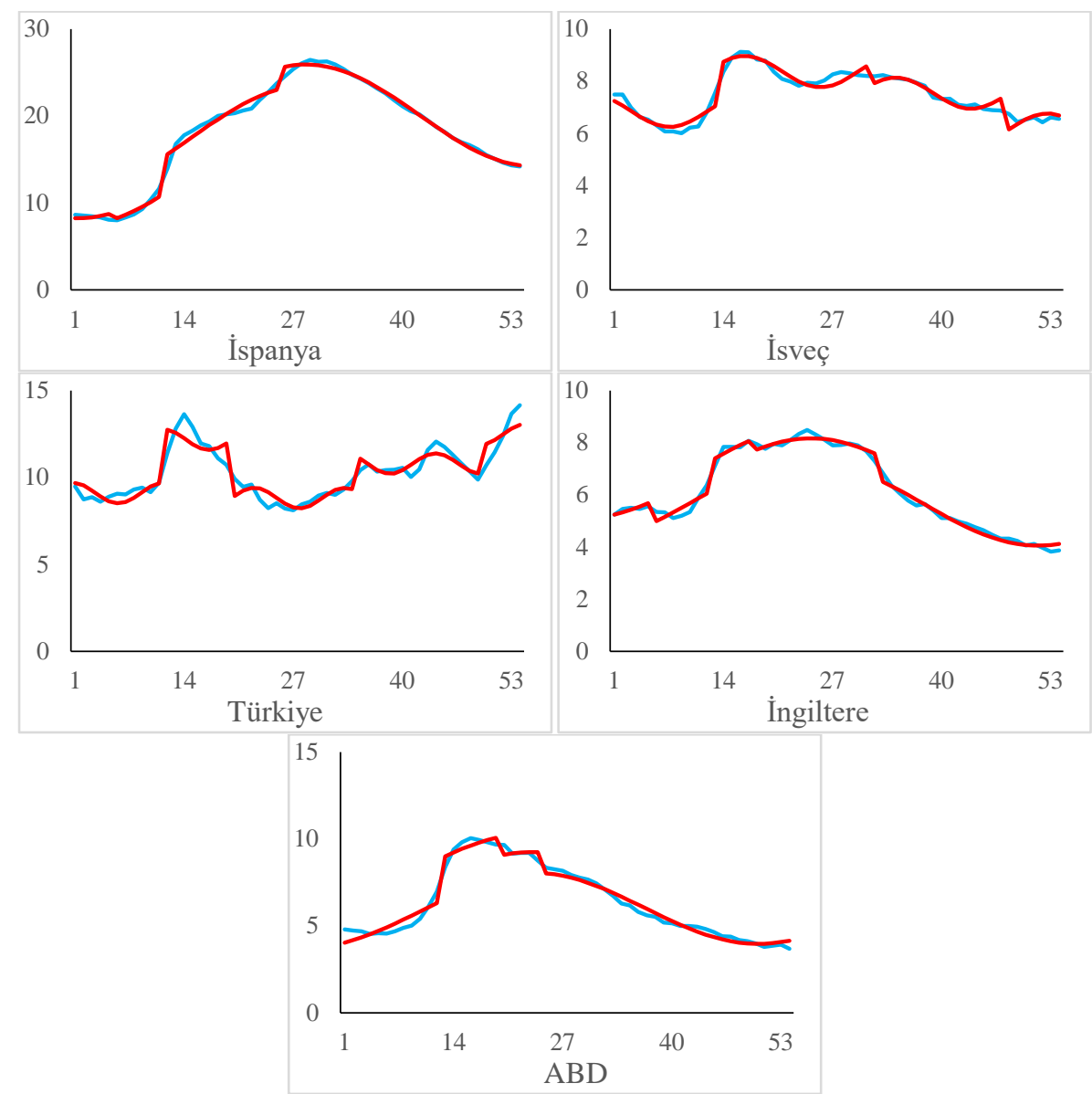

Şekilde mavi olarak temsil edilen eğriler gerçekleşen zaman yolunu, kırmızı olarak temsil edilen eğriler ise tahmini zaman yolunu göstermektedir. Hem keskin hem de yumuşak geçişler ile elde edilen tahmini zaman yolu gerçekleşen zaman yolunu iyi bir şekilde yansitmaktadır. $\mathrm{Bu}$ durum da doğrusal olmayan fonksiyonların analize dâhil edilmesi gerekliliğini doğrulamaktadır. Son olarak, panel durağanlık testi uygulanmadan önce keskin geçişlerin tarihleri belirlenmiştir.

Tablo 5'te 1 ile 5 arasında bir sayıda keskin kırılma tarihleri yer almaktadır. İlgili dönem aralığında işsizlik serisinin en çok yapısal kırılma içerdiği ülkeler sırasıyla Almanya, İtalya, Hollanda, Norveç, Türkiye ve İngiltere'dir. ABD'de ilk yapısal kırılma tarihi 2008 küresel krizini göstermektedir. Bu krizden birçok ülke etkilenmiştir. 1. ve 2. yapısal kırılma tarihlerine bakıldığında Avusturya, Belçika, Danimarka, Fransa, Almanya, Hollanda, Norveç, Portekiz, İspanya, İsveç, Türkiye, İngiltere ve ABD'de işsizlik oranlarının 20072008 finansal krizinden etkilendiği görülmektedir. Yunanistan'da ise ilk ve tek kırılma tarihi 2011 yılıdır. 2011 yılında Yunanistan dış borç krizi yaşanmıştır. Bu yılda ülkede ciddi kemer sıkma politikaları uygulanmış ve Yunan hükümeti bu krizi aşmak için yüksek getiri sağlayan hükümet tahvilleri ile borçlanmıştır. Kemer sıkma politikaları nedeniyle istihdam daralmıştır. İtalya'da 3. kırılma tarihi olan 2013 yılında işsizlik oranı bir önceki yıla göre 1,5 puan 
OECD Ülkelerinde İşsizlik Histerisinin Ampirik Bir Analizi: Fourier Panel Durağanlık Testi

artmıştır. Türkiye'de son kırılma tarihi olan 2018 yılında işsizlik oranı Şubat'ta \%9,8 iken Aralık'ta \%12,8'e yükselmiştir.

Tablo 5. Keskin Kırılma Tarihleri

\begin{tabular}{|c|c|c|c|c|c|}
\hline Ülkeler & $\mathrm{TB}_{1}$ & $\mathrm{~TB}_{2}$ & $\mathrm{~TB}_{3}$ & $\mathrm{~TB}_{4}$ & $\mathrm{~TB}_{5}$ \\
\hline Avusturya & $2007 q 3$ & $2008 q 4$ & 2010q3 & - & - \\
\hline Belçika & $2007 q 2$ & 2010q4 & - & - & - \\
\hline Danimarka & 2007q1 & 2009q1 & - & - & - \\
\hline Fransa & $2007 q 3$ & $2008 q 4$ & 2010q3 & - & - \\
\hline Almanya & 2007q1 & 2008q2 & 2010q1 & $2011 q 3$ & $2015 q 4$ \\
\hline Yunanistan & $2011 \mathrm{q} 3$ & - & - & - & - \\
\hline İtalya & $2010 \mathrm{q3}$ & $2011 q 4$ & 2013q1 & $2016 q 2$ & - \\
\hline Hollanda & $2007 q 3$ & 2010q3 & 2013q1 & $2016 q 2$ & - \\
\hline Norveç & $2007 q 3$ & $2009 q 2$ & $2014 q 4$ & $2017 q 2$ & - \\
\hline Portekiz & $2007 q 4$ & $2012 q 2$ & $2013 q 3$ & - & - \\
\hline İspanya & 2007q1 & $2008 q 3$ & $2012 q 2$ & - & - \\
\hline İsveç & 2009q1 & $2013 q 3$ & $2017 q 3$ & - & - \\
\hline Türkiye & $2008 \mathrm{q3}$ & $2010 \mathrm{q3}$ & $2014 q 2$ & 2018q1 & - \\
\hline İngiltere & 2007q1 & $2008 q 4$ & 2010q1 & 2014q1 & - \\
\hline $\mathrm{ABD}$ & $2008 \mathrm{q} 3$ & $2010 \mathrm{q} 3$ & $2011 q 3$ & - & - \\
\hline
\end{tabular}

Not: Maksimum 5 kırılmaya izin verilmiştir. TB: Kırılma tarihi.

Tablo 6. Fourier-CBL Panel Durağanlık Testi Sonuçları

\begin{tabular}{lcccc}
\hline Ülkeler & Barlett test istatistiği & $\% 10$ & $\% 5$ & $\% 1$ \\
\hline Avusturya & 0.0406 & 0.0455 & 0.0526 & 0.0671 \\
\hline Belçika & 0.0444 & 0.0841 & 0.1072 & 0.1585 \\
\hline Danimarka & 0.0362 & 0.0574 & 0.0690 & 0.0934 \\
\hline Fransa & 0.0387 & 0.0454 & 0.0523 & 0.0673 \\
\hline Almanya & 0.2964 & 0.0415 & 0.0483 & 0.0615 \\
\hline Yunanistan & 0.0521 & 0.1418 & 0.1840 & 0.2784 \\
\hline İtalya & 0.0584 & 0.0470 & 0.0551 & 0.0743 \\
\hline Hollanda & 0.0448 & 0.0481 & 0.0567 & 0.0752 \\
\hline Norveç & 0.0747 & 0.0795 & 0.1014 & 0.1526 \\
\hline Portekiz & 0.0495 & 0.0769 & 0.0977 & 0.1458 \\
\hline İspanya & 0.0325 & 0.0615 & 0.0773 & 0.1159 \\
\hline İsveç & 0.0551 & 0.0672 & 0.0802 & 0.1108 \\
\hline Türkiye & 0.1530 & 0.0616 & 0.0728 & 0.0991 \\
\hline İngiltere & 0.0375 & 0.0419 & 0.0490 & 0.0666 \\
\hline ABD & 0.0547 & 0.0622 & 0.0776 & 0.1126 \\
\hline PANKPSS-heterojen & -0.1718 & -1.0906 & -1.546 & -2.004 \\
PANKPSS-homojen & -1.3424 & -1.8035 & -2.475 & -3.191 \\
\hline
\end{tabular}

Not: Tablo kritik değerleri 20,000 Monte Carlo simülasyonu tekrarı ile elde edilmiştir. PANKPSS: Panelin tamamı için KPSS test istatistiği. 
F-istatistiği ile doğrusal olmayan yapıların durağanlık testinde kullanılması gerektiğine karar verdikten ve keskin geçişleri belirledikten sonra yumuşak geçişleri de dikkate alarak işsizlik serisinin durağanlığı Fourier-CBL panel durağanlık testi ile analiz edilmiştir. Gerçekleştirilen teste ait sonuçlar Tablo 6'da gösterilmektedir. Tablodaki sonuçlara göre Almanya, İtalya ve Türkiye'de işsizlik oranı birim kök içermektedir. Bu ülkelerde şokların işsizlik oranındaki etkileri kalıcıdır. İşsizlik oranındaki olumsuz gelişmelerin giderilmesi için hükümet müdahalesi gerekmektedir. Avusturya, Belçika, Danimarka, Fransa, Yunanistan, Hollanda, Norveç, Portekiz, İspanya, İsveç, İngiltere ve ABD'de ise işsizlik oranları durağandır. Bu ülkelerde şokların işsizlik oranlarına etkileri geçicidir. 15 OECD ülkesinin 12 'sinde doğal oran hipotezi geçerlidir. Ayrıca heterojen PANKPSS test istatistiği de işsizlik oranının durağan olduğunu, diğer bir deyişle panelin geneli için işsizlik histerisinin reddedildiğini belirtmektedir. Hem ülke özelinde hem de panel genelinde elde edilen bu bulgular OECD ülkelerinde işsizlik konusunda hükümet müdahalelerinin gerekli olmadığını göstermektedir. İşsizlik oranları uzun dönem ortalama değerine geri dönme eğilimindedir.

\section{SONUÇ}

$\mathrm{Bu}$ çalışmada 15 OECD ülkesi için işsizlik histerisi hipotezinin geçerliliği sınanmıştır. İşsizlik histerisi sınanırken yatay kesit bağımlılığı, eğim heterojenliği ve keskin geçişlerin yanında yumuşak geçişler dikkate alınmıştır. Çalışmada ilk olarak OECD ülkeleri arasında işsizlik oranlarının yatay kesit bağımlılı̆̆ı içerip içermediği ve eğimin heterojen bir yapıya sahip olup olmadığ ${ }_{1}$ analiz edilmiştir. Gerçekleştirilen testler sonucunda bir ülkede işsizlik için oluşan şokun diğer OECD ülkelerindeki işsizlik oranlarını da etkileyebileceği ve eğimin heterojen bir yapıya sahip olduğu belirlenmiştir. Bu nedenle çalışmada yatay kesit bağımlılığı ve heterojenliği dikkate alan Fourier-CBL panel durağanlık testi kullanılmıştır.

F-testi ile durağanlık analizinde trigonometrik terimlerin yer alması gerektiğine karar verilmiş ve bu nedenle sert geçişlerin yanında yumuşak geçişler de dikkate alınmıştır. Fourier CBL panel durağanlık testi ile elde edilen üç önemli bulgu söz konusudur: I) Türkiye, Almanya ve İtalya'da işsizlik serileri birim kök içermektedir. II) Geriye kalan 12 ülkede işsizlik serileri durağandır. III) Panelin tamamı için işsizlik histerisi hipotezi geçerli değildir. Bu bulgular Özcan (2012), Marques, Tadeu ve Troster (2017), Tiraşoğlu (2019)'nun sonuçlarının aksine, Chang (2011), Meng, Strazicich ve Lee (2017) ve Khraief, Shahbaz, Heshmati ve Azam (2018)'nin belirttiği gibi işsizlik histerisi hipotezinin OECD ülkeleri için geçerli olmadığını göstermektedir.

Almanya, İtalya ve Türkiye'de işsizlik oranları üzerinde oluşacak olumsuz şoklar kalıcı etkilere sahip olabilmektedir. Böylece artan işsizlik oranı zamanla doğal işsizlik oranının yerini almaktadır. Ekonomik krizler bu ülkeler için oldukça maliyetlidir. Almanya çalışmanın örnekleminde 2006 yılında en yüksek işsizlik oranına sahip olan ülke konumundayken, 2019'un ikinci çeyreğinde 15 OECD üyesi ülke arasında en düşük işsizliğe sahip ülke olarak yer almaktadır. Bu durum Almanya'nın işsizliği azaltma hususunda oldukça başarılı bir politika izlediğinin göstergesidir. Bu nedenle Almanya için işsizlik histerisi şu an çok büyük bir problem olarak yer almamaktadır. Ancak Türkiye ve İtalya'da işsizlik çift hanelerde seyretmektedir. İtalya 2011 yılının son çeyreğine kadar tek haneli bir işsizlik oranına sahip olsa da bu yıldan itibaren işsizlik sürekli çift hanelerde kalmıştır. Türkiye'de ise 2010 yılı dördüncü ve 2014 yılı ikinci çeyreği arasında işsizlik oranı tek haneye inmiş, 2018 yılı ilk çeyreği haricinde son 5 yıldır işsizlik oranı çift hanelerde seyretmiştir. 2019 yılının ikinci çeyreğinde İtalya ve Türkiye'de işsizlik oranları sırasıyla yaklaşı \% 10 ve \%14 olarak gerçekleşmiştir. Bu ülkelerde işsizliğin kalıcı olması önemli bir problemdir. İşsizlik histerisi bu nedenle çözülmesi gereken bir husustur. 
Türkiye, İtalya ve Almanya'da işsizliği önlemek için devlet müdahalesi gerekmektedir. Genişletici para ve maliye politikaları ile yeni istihdam alanları yaratmak oldukça önemlidir. Toplam talebi arttırıcı politikalar bu ülkelerde istihdam artışı sağlayabilmektedir. Almanya bu konuda başarılı olmuş ve 10 yıllık süreçte işsizlik oranlarını önemli ölçüde geriletmiştir. Türkiye ve İtalya'da işsizlik ile mücadelede uygulanan politikaların ise yeterli etkiye sahip olmadığg görülmektedir.

Diğer taraftan, Avusturya, Belçika, Danimarka, Fransa, Yunanistan, Hollanda, Norveç, Portekiz, İspanya, İsveç, İngiltere ve ABD'de işsizlik oranları durağandır. Bu 12 ülkede işsizlik oranı üzerindeki olumlu veya olumsuz şokların etkileri kalıcı olmayacaktır. Dolayısıyla bahsi geçen ülkelerde işsizlik histerisi geçerli değildir. Ayrıca bu ülkelerde işgücü piyasasını düzenleyici makroekonomik politikalar sadece geçici değişikliklere sebebiyet verecektir. Yunanistan'da işsizlik oranı bir dönem \%30'lara yaklaştıysa da 2019'un ikinci çeyreğinde \%17’ye gerilemiştir. Yunanistan'da işsizlik oranı uzun dönemde denge değerine geri dönme eğilimindedir. Ayrıca bu 12 ülkede işsizlik oranının geçmiş değerleri göz önünde bulundurularak gelecek değerleri tahmin edilebilir. Böylece işsizliğin ne doğrultuda ilerlediği tespit edilebilir. Türkiye, Almanya ve İtalya için bu durum söz konusu değildir.

Sonuçları genelleyecek olursa ülke özelinde 15 OECD ülkesinin yaklaşı \%80'inde ve panelin tamamında işsizlik histerisi hipotezi geçerli değildir. Bu nedenle işsizliği önlemek için ekonomiye 12 OECD ülkesinde müdahale edilmemesi gerekmektedir. İşgücü piyasasına hükümet tarafından gerçekleştirilecek müdahaleler sadece geçici çözümlere ve kaynakların etkin kullanılmamasına sebebiyet verecektir

\section{Kaynakça}

Arestis, P. and Mariscal, I. B. F. (1999). Unit Roots and Structural Breaks in OECD Unemployment. Economics Letters. 65(2). 149156. doi: 10.1016/S0165-1765(99)00131-7.

Arestis, P. and Mariscal, I. B. F. (2000). OECD Unemployment: Structural Breaks and Stationarity. Applied Economics. 32(4). 399403. doi: $10.1080 / 000368400322570$.

Ağazade, S. (2016). Türkiye için İşsizlik Histerisine Karşın Doğal Oran Hipotezinin Doğrusal Dışı Yöntemlerle Sınanması. Sosyal Güvenlik Dergisi. 6(2). 28-46.

Bahmani-Oskooee, M., Chang, T. and $\mathrm{Wu}, \mathrm{T}$. (2014). Revisiting Purchasing Power Parity in African Countries: Panel Stationary Test with Sharp and Smooth Breaks. Applied Financial Economics. 24(22). 1429-1438. doi: 10.1080/09603107.2014.925068.

Bahmani-Oskooee, M., Chang, T. and Wu, T. P. (2015). Purchasing Power Parity in Transition Countries: Panel Stationary Test with Smooth and Sharp Breaks. International Journal of Financial Studies. 3(2). 153-161. doi: 10.3390/ijfs3020153.
Becker, R., Enders, W. and Lee, J. (2006). A Stationarity Test in the Presence of an Unknown Number of Smooth Breaks. Journal of Time Series Analysis. 27(3). 381-409. doi: 10.1111/j.1467-9892.2006.00478.x.

Bekmez, S. ve Özpolat, A. (2016). Hysteresis Effect on Unemployment for Men and Women: A Panel Unit Root Test for OECD Countries. International Journal of Financial Research. 7(2). 122-133. doi: 10.5430/ijfr.v7n2p122.

Blanchard, O. J. and Summers, L. H. (1986). Hysteresis in Unemployment, Massachusetts Institute of Technology Deptartment of Economics 430.

Breusch, T. S. and Pagan, A. R. (1980). The Lagrange Multiplier Test and Its Applications to Model Specification in Econometrics. The Review of Economic Studies. 47(1). 239-253. doi: $10.2307 / 2297111$.

Camarero, M. and Tamarit, C. (2004). Hysteresis vs. Natural Rate of Unemployment: New Evidence for OECD Countries. Economics Letters. 84(3). 413-417. doi: 10.1016/j.econlet.2004.02.014. 
Camarero, M., Carrion-i-Silvestre, J. L. and Tamarit. C. (2006). Testing for Hysteresis in Unemployment in OECD Countries: New Evidence Using Stationarity Panel Tests with Breaks. Oxford Bulletin of Economics and Statistics. 68(2). 167-182. doi: 10.1111/j.14680084.2006.00157.x.

Canarella, G., Gupta, R., Miller, S. M. and Pollard, S. K. (2019). Unemployment Rate Hysteresis and the Great Recession: Exploring the Metropolitan Evidence. Empirical Economics. 56(1). 61-79. doi: 10.1007/s00181017-1361-z.

Carrion-i-Silvestre, J. L., Del Barrio-Castro, T. and López-Bazo, E. (2005). Breaking the Panels: An Application to the GDP Per Capita. The Econometrics Journal. 8(2). 159-175. doi: 10.1111/j.1368-423X.2005.00158.x.

Chang, T. (2011). Hysteresis in Unemployment for 17 OECD Countries: Stationary Test with a Fourier Function. Economic Modelling. 28(5). 2208-2214. doi: 10.1016/j.econmod.2011.06. 002

Darity Jr, W. and Goldsmith, A. H. (1993). Unemployment, Social Psychology and Unemployment Hysteresis. Journal of Post Keynesian Economics. 16(1). 55-71. doi: 10.1080/01603477.1993.11489969

Dickey, D. A. and Fuller, W. A. (1981). Likelihood Ratio Statistics for Autoregressive Time Series with a Unit Root. Econometrica: Journal of the Econometric Society. 49(4). 10571072. doi: 10.2307/1912517.

Enders, W. and Lee, J. (2012). The Flexible Fourier form and Dickey-Fuller Type Unit Root Tests. Economics Letters. 117(1). 196-199. doi: 10.1016/j.econlet.2012.04.081.

Ener, M. and Arica, F. (2011). Is there Hysteresis in Unemployment in OECD Countries? Evidence from Panel unit Root Test with Structural Breaks. Chinese Business Review. 10(4). 294-304.

Fosten, J. and Ghoshray, A. (2011). Dynamic Persistence in the Unemployment Rate of OECD Countries. Economic Modelling. 28(3). 948-954. doi: 10.1016/j.econmod.2010.11.007.

Friedman, M. (1968). The Role of Monetary Policy. American Economic Review. 58(1). 117.
Gustavsson, M. and Österholm, P. (2010). The Presence of Unemployment Hysteresis in the OECD: What Can We Learn from Out-ofSample Forecasts? Empirical Economics. 38(3). 779-792. doi: 10.1007/s00181-009-0290-x.

Lee, C. C. and Chang, C. P. (2008). Unemployment Hysteresis in OECD Countries: Centurial Time Series Evidence with Structural Breaks. Economic Modelling. 25(2). 312-325. doi: 10.1016/j.econmod.2007.06.002.

Lee, J. D., Lee, C. C. and Chang, C. P. (2009). Hysteresis in Unemployment Revisited: Evidence from Panel LM Unit Root Tests with Heterogeneous Structural Breaks. Bulletin of Economic Research. 61(4). 325-334. doi: 10.1111/j.1467-8586.2008.00287.x.

FRED (2019). FRED ${ }^{\circledR}$ Economic Data. [https://fred.stlouisfed.org/]. (Erişim: 17 Aralık 2019).

Gallant, A. R. (1981). On the Bias in Flexible Functional Forms and an Essentially Unbiased form: The Fourier Flexible Form. Journal of Econometrics. 15(2). 211-245. doi: 10.1016/0304-4076(81)90115-9.

Khraief, N., Shahbaz, M., Heshmati, A. and Azam, M. (2020). Are Unemployment Rates in OECD Countries Stationary? Evidence from Univariate and Panel Unit Root Tests. The North American Journal of Economics and Finance. 51. 100838. doi: 10.1016/j.najef.2018.08.021.

Kwiatkowski, D., Phillips, P. C., Schmidt, P. and Shin, Y. (1992). Testing the Null Hypothesis of Stationarity Against the Alternative of a Unit Root: How Sure Are We that Economic Time Series Have a Unit Root? Journal of Econometrics. 54(1-3). 159-178. doi: 10.1016/0304-4076(92)90104-Y.

Marques, A. M., Lima, G. T. and Troster, V. (2017). Unemployment Persistence in OECD Countries After the Great Recession. Economic Modelling. $64 . \quad 105-116 . \quad$ doi: 10.1016/j.econmod.2017.03.014.

Meng, M., Strazicich, M. C. and Lee, J. (2017). Hysteresis in Unemployment? Evidence from Linear and Nonlinear Unit Root Tests and Tests With Non-Normal Errors. Empirical Economics. 53(4). 1399-1414. doi: 10.1007/s00181-0161196-z 
Mitchell, W. F. (1993). Testing for Unit Roots and Persistence in OECD Unemployment Rates. Applied Economics. 25(12). 1489-1501. doi: 10.1080/00036849300000153

Murray, C. J. and Papell, D. H. (2000). Testing For Unit Roots in Panels in the Presence of Structural Change with an Application to OECD Unemployment. Advances in Econometrics. 15. 223-238.

Özcan, B. (2012). İşsizlik Histerisi Hipotezi OECD Ülkeleri için Geçerli mi? Yapısal Kırılmalı Birim Kök Analizi. Erciyes Üniversitesi İktisadi ve İdari Bilimler Fakültesi Dergisi. 40. 95-117.

Papell, D. H., Murray, C. J. and Ghiblawi, H. (2000). The Structure of Unemployment. Review of Economics and Statistics. 82(2). 309-315. doi: 10.1162/003465300558696

Perron, P. (1989). The Great Crash, the Oil Price Shock, and the Unit Root Hypothesis. Econometrica: Journal of the Econometric Society. 57(6). 1361-1401. doi: 10.2307/1913712.

Pesaran, M. H. 2004. General Diagnostic Tests for Cross Section Dependence in Panels. Cambridge Working Papers in Economics No. 435. University of Cambridge and CESifo Working Paper Series No. 1229.

Pesaran, M. H. and Yamagata, T. (2008). Testing Slope Homogeneity in Large Panels. Journal of Econometrics. 142(1). 50-93. doi: 10.1016/j.jeconom.2007.05.010.

Pesaran, M. H. (2015). Testing Weak CrossSectional Dependence in Large Panels. Econometric Reviews, 34(6-10). 10891117. doi: 10.1080/07474938.2014.956623.

Phelps, E. S. (1967). Phillips Curves, Expectations of Inflation and Optimal Unemployment over Time. Economica. 34(135). 254-281. doi: 10.2307/2552025.

Phelps, E. S. (1968). Money-Wage Dynamics and Labor-Market Equilibrium. Journal of Political Economy. 76(4). 678-711. doi: 10.1086/259438.

Phelps, E. S. (1994). Structural Slumps: The Modern Equilibrium Theory of Unemployment, Interest and Assets. Cambridge: Harvard University Press.
Phelps, E. S. (1999). Behind This Structural Boom: The Role of Asset Valuations. American Economic Review. 89(2). 63-68. doi: 10.1257/aer.89.2.63.

Phelps, E. S. and Zoega, G. (1998). Natural-Rate Theory and OECD Unemployment. The Economic Journal. 108(448). 782-801.

Pissarides, C. A. (1992). Loss of Skill During Unemployment and the Persistence of Employment Shocks. The Quarterly Journal of Economics. 107(4). 1371-1391. doi: $10.2307 / 2118392$.

Røed, K. (1996). Unemployment HysteresisMacro Evidence From 16 OECD Countries. Empirical Economics. 21(4). 589-600. doi: 10.1007/BF01180703

Smyth, R. (2003). Unemployment Hysteresis in Australian States and Territories: Evidence from Panel Data Unit Root Tests. Australian Economic Review. 36(2). 181-192. doi: 10.1111/1467-8462.00278.

Song, F. M. and Wu, Y. (1998). Hysteresis in Unemployment: Evidence from OECD Countries. The Quarterly Review of Economics and Finance. 38(2). 181-192. doi: 10.1016/S1062-9769(99)80111-2.

Tiraşoğlu, M. (2019). Unemployment Hysteresis Analysis for OECD Countries. Theoretical \& Applied Economics. 4(621). 53-62.

Yalçınkaya, Ö. ve Kaya, V. (2017). Doğal İsssizlik Oranı mı Yoksa İsssizlik Histerisi mi? OECD Ülkeleri için Yeni Nesil Panel Birim Kök Testlerinden Kantlar (1980-2015). Sosyal Ekonomik Araştırmalar Dergisi. 17(33). 1-18.

Yerdelen Tatoğlu, F. (2013). Panel Veri Ekonometrisi. 2. Bask1. Beta Yayınevi. İstanbul.

Yilanci, V. (2008). Are Unemployment Rates Nonstationary or Nonlinear? Evidence from 19 OECD Countries. Economics Bulletin. 3(47). 15.

Zivot, E. and Andrews, D.W.K. (1992). Further Evidence on the Great Crash, the Oil Price Shock and the Unit-Root Hypothesis. Journal of Business \& Economic Statistics. 10(3). 251-270. doi: 10.1198/073500102753410372. 
